\title{
Sphincteric Ureterocele
}

National Cancer Institute

\section{Source}

National Cancer Institute. Sphincteric Ureterocele. NCI Thesaurus. Code C123239.

A ureterocele in which the orifice is distal to the external urinary sphincter. 